\title{
The seductive effect of identical physical units
}

\section{Other Journal Item}

Author(s):

Frischknecht, Rolf (iD)

Publication date:

1997

Permanent link:

https://doi.org/10.3929/ethz-b-000423078

Rights / license:

In Copyright - Non-Commercial Use Permitted

Originally published in:

The International Journal of Life Cycle Assessment 2(3), https://doi.org/10.1007/BF02978800 


\section{Letters to the Editor}

In Defense of the Cumulative Energy Demand (Editorial) by Walter Klöpffer, Int. J. LCA 2 (2) 61 (1997)

\section{The Seductive Effect of Identical Physical Units}

In the last edition of the "International Journal of Life Cycle Assessment", W. KLÖPFFER (1997) suggests that the cumulative energy demand (CED) be included in the impact assessment or valuation phase of LCA. While I agree on the proposal in general, I have serious objections to the author's argumentation as to why CED should be seen as an important indicator. This letter will comment on K1.ÖPFFFR's argumentation, and present some, still rather fuzzy recommendations for further research.

KI.OPFFt:R (1997) starts by citing two frequently cited arguments whereby, according to his understanding as well, CED should not be included:

(1) The danger of double counting together with in impact assessment,

(2) the primary indicators should be an unaggregated resource demand from which CED is derived.

Subsequently, the four reasons provided by KI.OHYWl:R (1997) as to why CED is important in LCA are summarized, and are commented individually:

$1 \mathrm{CED}$ is the only energy parameter which aggregates all forms of energy use over the entire life cycle. Removing it would exclude some form of energy (especially non-fossil forms) from the impact assessment.

Energy expressed in $\mathrm{MJ}$ is not an environmental intervention nor an impact (eventually disregarding waste heat ${ }^{1}$ ). The problem that some forms of energy are not considered in the impact assessment if CED is removed originates from the fact that the environmental impacts of these forms of energy are not, not yet or not sufficiently, considered in today's impact assessment methods. An attempt to overcome this shortcoming concerning radioactive releases is made by, e.g., SOlberg et al. (1997).

\footnotetext{
1 The impacts of emissions such as radiation and noise are of course connected to a certain energy flow but are measured differently.
}

2 CED implicitly indicates the environmental interventions due to energy consumption.

If this statement is regarded as being true, it would have the following implications:

The environmental interventions of $1 \mathrm{kWh}$ electricity produced in a thermal power plant are weighted equivalently disregarding the production technology (nuclear power plant, or conventional lignite, hard coal, fuel oil or natural gas power plant). Moreover, if we include hydro power into the CED indicator, $1 \mathrm{kWh}$ electricity from a thermal power plant has about the same environmental performance as $3 \mathrm{kWh}$ from a hydro power plant (assuming 90 to $100 \%$ efficiency of hydro power).

\section{CED does not depend on any assumptions.}

This argument is somewhat linked to the former. To use CED as a proxy for environmental impacts is the first and most critical assumption. To derive the CED from an inventory table further implies a long list of assumptions to be made, i.e. the environmental impacts due to $1 \mathrm{MJ}$ of crude oil equal to the ones of $1 \mathrm{MJ}$ of uranium (what exactly is 1 MJ of uranium anyway?), etc. These assumptions should be closely linked to the safeguard subjects covered with CED (see "Concluding Remarks" below).

3.1 Should renewable, sustainably used energy resources (like solar radiation, wind, water and biomass) be included in the CED?

If they are not included, photovoltaic power plants, for instance, do have positive energy harvesting factors. If they are included and, if the solar energy radiated on a PV panel is used, for example, the overall efficiency is as low as about $10 \%$. A similar reasoning may be applied for wind power and biomass fuels. If renewable energy is included one might even argue in favor of considering the solar energy required to evaporate and transport the water from the oceans to the mountains, thus feeding hydro storage power. 
3.2 How should one account for the fission energy of nuclear energy?

In principle, Einstein provided us with the formula to compute the maximum available energy when mass is converted to energy (see e.g., FRISCHKNECHT et al. 1995). In a nuclear reactor, only a very small portion of this energy is made available. Should we therefore rely on the energy that is usable with today's technology? This would imply the use of the gross energy contents of fossil and biomass fuels since these technologies are mandatory to make use of the condensation energy of steam in the flue gas streams.

\subsection{Should the resources wasted along the process chain be in- cluded or not?}

Energy resources may be spoiled during extraction, refinement and transportation. Should these wastes be energetically weighted similar to the part that is used in a boiler or a power plant? In the case of nuclear energy about one third of the fissionable uranium mined is wasted in the enrichment process. However, this uranium is not lost, although a significantly higher effort is required to extract it.

\subsection{How to deal with feedstock energy?}

This question arises in the case of recycling and downcycling and encounters the same lively discussions as for the rest of life cycle inventory items (economic and environmental flows) of a classical LCA.

4 The accuracy of the CED calculation is much greater than that of most characterization procedures.

This holds true if the problems and questions listed above are answered. Nevertheless, the accuracy is limited to the figure CED. How accurate CED models environmental impacts and the question whether or not CED is an adequate and accurate sum-parameter or streamlining indicator for environmental interventions is doubtful.

\section{Concluding Remarks}

In my opinion, CED is a weighting scheme used as a shortcut indicator in the impact assessment of a streamlining LCA. The calculation rules needed to aggregate the various energy carriers or energy resources are not standardized ${ }^{2}$ nor are they undisputed. We strongly suggest that these rules be defined in accordance to the protection goals and safeguard subjects in mind when speaking of CED. Possible safeguard subjects may be:

- Fossil energy resources (oil, gas, coal)

- fissionable energy resources (uranium)

- non-renewable energy resources (oil, gas, coal and uranium)

- overall energy demand

\footnotetext{
2 In VDI (1997) several options to weight renewable and fission energies (like substitution method) are given. The decision whether to use the upper or lower heating value is not taken.
}

- impacts (i.e., global warming, acidification, human toxicological impacts, etc. ${ }^{3}$ ), due to non-renewable energy resources (oil, gas, coal, uranium) ${ }^{4}$

- impacts (i.e., global warming, acidification, human toxicological impacts, etc.) due to energy resources (oil, gas, coal, uranium, biomass, water, wind, photovoltaic $)^{4}$

Because CED is an outcome of the impact assessment, we resigned from using it in the Life Cycle Inventories for Energy Systems (FRISCHKNECHT et al. 1994/1996), which only covers the goal and scope definition and inventory analysis. However, with the unaggregated elementary flows of resource use ( $\mathrm{kg}$ hard coal, lignite, uranium, TJ potential energy of water, etc.) given in FRISCHKNECHT et al. (1994/ 1996), the possibility to calculate CED is given.

In a forthcoming article in this journal (FRISCHKNECHT et al. 1998), the implications of various energy accounting methods will be further discussed in relation to environmental safeguard subjects.

\section{References}

Anonymous (1997): ISO/ TC 207/ SC 5/ N 109, Draft International Standard 14041, 1997.01.10, Environmental Management - Life Cycle Assessment - Goal and Scope Definition and Inventory Analysis

SolBH:R(i-JoIANSE: B.; R. CIIIT; A. JWAP:S (1997): Irradiating the Environment: Radiological Impacts in Life Cycle Assessment. Int. J. I.CA 2 (I) 16-19

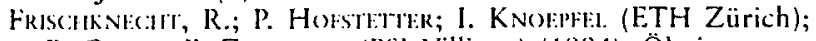
R. Donls; E. Zontingiter (PSI Villigen) (1994): Ökoinventare für Energiesysteme. Grundlagen für den ökologischen Vergleich von Energiesystemen und den Einbezug von Energiesystemen in Ökobilanzen für die Schweiz. I. Edition, Gruppe Energie Stoffe - Unwelt, ETH Zürich, Sektion Ganzheitliche Systemanalysen, PSI Villigen

Frisciknicit, R.; P. HolsteTtlek (1995): Reply to Energy data in Envirommental L.C.A. LCA News 5:1, pp. 6-7

Frischiknicht, R. (final editor); U. Bolli:NS; S. Bosshart; M. CIOT; L. CISl:RI; G. DokA; R. Hisciller; A. MarTin (ETH Zürich); R. Dones; U. GavtNi:R (PSI Villigen) (1996): Ökoinventare von Energiesystemen. Grundliagen für den ökologischen Vergleich von Energiesystemen und den Einbezug von Energiesystemen in Ökobilanzen für die Schweiz, 3. Edition, Gruppe Energie Stoffe - Umwelt, ETH Zürich, Sektion Ganzheitliche Systemanalysen, PSI Villigen

FrisCHKNeCHT, R; R. HeIJUNGS; P. HOFSTETTER (1988): Einstein's lessons for energy accounting in LCA. Submitted to Int. J. LCA

KLÖPFFER, W. (1997): In Defense of the Cumulated Energy Demand. Int. J. LCA 2 (2) 61

Udo dE HAEs, H.A. (Ed.) (1996): Towards a Methodology of Life Cycle Impact Assessment, SETAC, Brussels

Verein Deutscher Ingenieure (VDI, Ed.) (1997): Kumulierter Energieaufwand: Begriffe, Definitionen, Berechnungsmethoden. VDI-Richtlinie 4600. Beuth-Verlag, D-10772 Berlin, Germany (Issue German-English, June 1997: Cumulative Energy Demand: Terms, Definitions, Methods of Calculation)

Rolf Frischknecht

Chemical Engineering Department Safety \& Environmental Technology Group ETH Zurich

\footnotetext{
3 see, e.g., UDO DE HAES (1996) for a possible list of impacts.

4 Implies the assumption, that the impacts caused by environmental flows due to one technology per unit CED is equal to the (sometimes very different) impacts caused by distinct environmental flows of another technology (see text above).
} 